\title{
A Comparative Study on the Hydrocracking for Atmospheric Residue of Mongolian Tamsagbulag Crude Oil and Other Crude Oils
}

\author{
Tserendorj Tugsuu ${ }^{1}$, Sugimoto Yoshikazu ${ }^{2}$, Byambajav Enkhsaruul ${ }^{1}$, Dalantai Monkhoobor ${ }^{1}$ \\ ${ }^{1}$ School of Chemistry and Chemical Engineering, National University of Mongolia, Ulaanbaatar, Mongolia \\ ${ }^{2}$ Energy Technology Research Institute, Advanced Industrial Science and Technology (AIST), Tsukuba, Japan \\ Email: tserendorj.tugsuu@yahoo.com,tugsuuts@num.edu.mn
}

Received March 12, 2012; revised April 10, 2012; accepted April 21, 2012

\begin{abstract}
Upgrading heavy and residual oils into valuable lighter fuels has attracted much attention due to growing worldwide demand for light petroleum product. This study focused on hydrocracking process for atmospheric residue (AR) of Mongolian crude oil in the first time compared to those of other countries. Residue samples were hydrocracked with a commercial catalyst at $450^{\circ} \mathrm{C}, 460^{\circ} \mathrm{C}, 470^{\circ} \mathrm{C}$ for 2 hours under hydrogen pressure of $10 \mathrm{MPa}$. The AR conversion and yield of light fraction (LF) reached to $90.6 \mathrm{wt} \%$ and $53.9 \mathrm{wt} \%$, at $470^{\circ} \mathrm{C}$ by the hydrocracking for atmospheric residue of Tamsagbulag crude oil (TBAR). In each sample, the yield of MF was the highest at $460^{\circ} \mathrm{C}$ temperature, which is valuable lighter fuel product. The polyaromatic, polar hydrocarbons and sulfur compounds were concentrated in the MF and HF because the large amount of light hydrocarbons produced from TBAR as the increasing of the hydrocracking temperature. The content of n-paraffinic hydrocarbons was decreased in HF of TBAR, on effect of hydrocracking temperature. This result suggests the longer molecules of n-paraffin $\left(\mathrm{C}_{20}-\mathrm{C}_{32}\right)$ in HF were reacted better, than middle molecules of n-paraffin $\left(\mathrm{C}_{12}-\mathrm{C}_{20}\right)$ in MF during the hydrocracking reaction. Because the hydrocarbon components of feed crude oils were various, the contents of n-paraffinic hydrocarbons in MF and HF of TBAR and DQAR were similar, but MEAR's was around 2 times lower and the hydrogen consumption was the highest for the MEAR after hydrocracking.
\end{abstract}

Keywords: Tamsagbulag Crude Oil; Hydrocracking; Atmospheric Residue; Sulfur Compound; N-Paraffinic Hydrocarbon

\section{Introduction}

Upgrading heavy and residual oils into valuable lighter fuels has attracted much attention due to growing worldwide demand for light petroleum product from declining reserves of sweet crude oils. Although there are large quantities of heavy oils such as atmospheric- and vacuum-distilled residual oils generated as byproducts in the refinery process, it is not easy to convert these residual oils into useful hydrocarbons [1-3]. Various methods, such as thermal cracking, catalytic cracking and hydrocracking are used to produce lighter fuels from heavy oils. In these methods, large hydrocarbon molecules of residual oil have broken up into smaller and more useful hydrocarbons by cracking reaction. Cracking process is called the hydrocracking, which is reacted under the hydrogen atmosphere, with a catalyst at high temperature and pressure [4].

Even though Mongolian Zuunbayan's petroleum refinery had been closed off in 1969, geological and chemical study of Mongolian crude oils has revived in the last 2 decades. Mongolian oils are paraffinic [5-7] and have low amounts of sulfur [8], heavy metals [9], which make some troubles to the refining processes of petroleum. However Mongolian crude oils contain a large amount of atmospheric residue, which should be converted into light and middle oils in order to produce motor fuel and chemicals [10]. Although the cracking process is important for refining of heavy residue, there is no research of cracking process for the atmospheric residue of Mongolian crude oils [11]. The present research has focused on the hydrocracking for the atmospheric residue of Tamsagbulag crude oil at different temperatures, with a commercial catalyst. On comparison with those of Chinese Daqing oil and Arabian mixed Middle East oil at same conditions.

\section{Experimental}

\subsection{Materials}

Three atmospheric residues (AR) were used in this study. 
AR of Mongolian Tamsagbulag crude oil is coded as TBAR; Chinese Daqing - as DQAR; Arabian mixed Middle East - as MEAR. The TB oil sample was supplied by "Daqing Tamsag" Company, which is doing a mining operation in Mongolia. DQAR and MEAR were obtained from Japanese petroleum refinery. The properties of atmospheric residues are shown in Table 1.

\subsection{Hydrocracking Test}

Hydrocracking of AR was carried out at $450^{\circ} \mathrm{C}, 460^{\circ} \mathrm{C}$ and $470^{\circ} \mathrm{C}$ for $2 \mathrm{~h}$ using a fixed bed reactor that was inserted into an electric furnace with vertically shaking type. About $4 \mathrm{~g}$ of atmospheric residue with $200 \mathrm{mg}$ of commercial catalyst was charged into the reactor, the inner volume of which was $50 \mathrm{ml}$. The reactor was pressurized by hydrogen gas up to $10 \mathrm{MPa}$ at ambient temperature, and then was heated to the prescribed temperature. Reaction temperature was maintained for 2 hours in every run, and all runs were repeated two times. Table 2 shows the conditions of the hydrocracking tests.

\subsection{Analysis}

Initially, atmospheric residue was separated using by a

Table 1. The properties of the atmospheric residues.

\begin{tabular}{ccccc}
\hline Properties & Unit & TBAR & DQAR & MEAR \\
\hline $\mathrm{C}$ & $\mathrm{wt} \%$ & 86.2 & 86.3 & 86.0 \\
$\mathrm{H}$ & $\mathrm{wt} \%$ & 13.1 & 13.1 & 11.9 \\
$\mathrm{~S}$ & $\mathrm{wt} \%$ & 0.18 & 0.12 & 2.47 \\
$\mathrm{~N}$ & $\mathrm{wt} \%$ & 0.16 & 0.16 & 0.13 \\
$\mathrm{H} / \mathrm{C}$ & atom $/$ atom & 1.82 & 1.82 & 1.66 \\
Saturate & $\mathrm{wt} \%$ & 57 & 59 & 44 \\
Aromatic & $\mathrm{wt} \%$ & 29 & 33 & 45 \\
Resin & $\mathrm{wt} \%$ & 9.5 & 5.8 & 7.2 \\
$\mathrm{C}_{5}$ Asphaltene & $\mathrm{wt} \%$ & 2.6 & 1.5 & 1.5 \\
$\mathrm{C}_{7}$ Asphaltene & $\mathrm{wt} \%$ & 1.4 & 0.3 & 2.6 \\
$\mathrm{Ni} / \mathrm{V}^{\mathrm{a}}$ & atom $/$ atom & $5 /<1$ & $6 / 1$ & $4 / 10$ \\
$\mathrm{CCR}$ & $\mathrm{wt} \%$ & 3.3 & 4.6 & 6.4 \\
\hline
\end{tabular}

${ }^{\mathrm{a}}$ Referred to an article, which is noted on reference [9].

Table 2. The condition of hydrocracking test.

\begin{tabular}{ccc}
\hline \multirow{2}{*}{ Sample } & Name & TBAR, DQAR, MEAR \\
& Weight & $4.0 \mathrm{~g}$ \\
Catalyst & Type & $\mathrm{NiMo} / \mathrm{Al}_{2} \mathrm{O}_{3}$ \\
& Weight & $0.2 \mathrm{~g}$ \\
$\mathrm{H}_{2} \mathrm{Gas}$ & Pressure & $10 \mathrm{MPa}$ \\
\multicolumn{2}{c}{ Temperature } & $450^{\circ} \mathrm{C}, 460^{\circ} \mathrm{C}, 470^{\circ} \mathrm{C}$ \\
\multicolumn{2}{c}{ Retention time } & 2 hours \\
\hline
\end{tabular}

distillation method to examine quantitatively its fractional composition. The hydrocracking product was handled as shown in Figure 1. At first, the toluene insoluble fraction was extracted from the hydrocracking products.

The toluene soluble fraction was recovered after solvent evaporation, then divided into four fractions by a distillation method: light fraction (LF) boiling point less than $220^{\circ} \mathrm{C}$, middle fraction (MF) boiling point of $220^{\circ} \mathrm{C}$ $350^{\circ} \mathrm{C}$, heavy fraction (HF) boiling point of $350^{\circ} \mathrm{C}-$ $500^{\circ} \mathrm{C}$ and bottom boiling point over than $500^{\circ} \mathrm{C}$. The separated distinct fractions were weighed to check a material balance including the yield of gases products.

After the reaction, gases products were subjected to Gas chromatography coupled with thermal conductivity detector (GC-TCD; Agilent, 6890) to estimate its composition. Then, contents of methane, ethane and propane gases were calculated using a calibration of standard gas samples. The Gas chromatography system coupled with a sulfur chemiluminescence detector (GC-SCD; Agilent 6890) was used to determine the sulfur content in liquid products from hydrocracking. The distillation curve of the liquid product was examined using a GC-FID system (Agilent, model 6890GC) that was equipped with a fused silica column $5 \mathrm{~m}$ long.

\subsection{Equations}

We used the following equations to calculate the conversion of AR (1), hydrogen consumption (2) and the yield of light fraction (3).

$$
\mathrm{C}_{\mathrm{AR}}=\frac{\mathrm{W}^{0}-\mathrm{W}^{1}}{\mathrm{~W}^{0}} \times 100 \%
$$

$\mathrm{C}_{\mathrm{AR}}-$ Convertion of $\mathrm{AR}, \mathrm{wt} \%$;

$\mathrm{W}^{0}$ - Initial weight of atmospheric residue, $\mathrm{g}$;

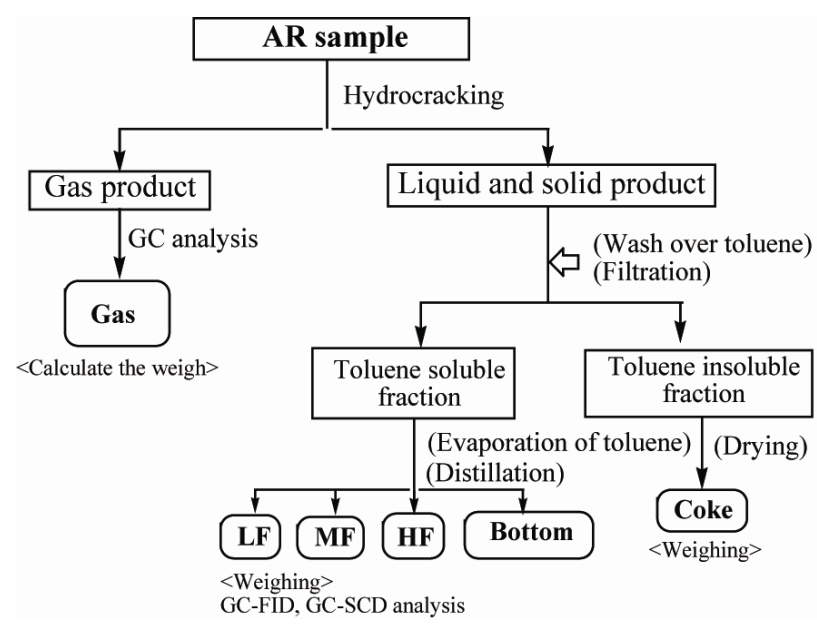

Figure 1. Product separation method of AR hydrocracking test (AR-Atmospheric residue of crude oil, LF-Light fraction, $<220^{\circ} \mathrm{C}$, MF-Middle fraction, $220^{\circ} \mathrm{C}-350^{\circ} \mathrm{C}$, HF-Heavy fraction, $350^{\circ} \mathrm{C}-500^{\circ} \mathrm{C}$, Bottom-Residue, $>500^{\circ} \mathrm{C}$ ). 
$\mathrm{W}^{1}$ - Weight of atmospheric residue after the reaction, $\mathrm{g}$;

$$
\mathrm{W}_{\mathrm{H} 2}=\frac{\mathrm{W}_{\mathrm{H} 2}^{0}-\mathrm{W}_{\mathrm{H} 2}^{1}}{\mathrm{~W}^{0}} \times 100 \%
$$

$\mathrm{W}_{\mathrm{H} 2}$ - Hydrogen consumption, $\mathrm{wt}^{\mathrm{t}} \%$;

$\mathrm{W}_{\mathrm{H} 2}^{0}$-Weight of hydrogen, which was charged into reactor, $\mathrm{g}$;

$\mathrm{W}_{\mathrm{H} 2}^{1}$-Weight of hydrogen after the reaction, $\mathrm{g}$;

$\mathrm{W}^{0}$ - Initial weight of atmospheric residue, $\mathrm{g}$.

$$
\begin{aligned}
\mathrm{W}_{\mathrm{LF}}= & \left(\mathrm{W}_{\mathrm{AR}}+\mathrm{W}_{\mathrm{H} 2}\right) \\
& -\left(\mathrm{W}_{\mathrm{Gas}}+\mathrm{W}_{\mathrm{MF}}+\mathrm{W}_{\mathrm{HF}}+\mathrm{W}_{\text {Bot }}+\mathrm{W}_{\text {Coke }}\right)
\end{aligned}
$$

According to the feature of the product separation method we calculated the yield of LF (3) from the material balance, which was limited from $100.4 \mathrm{wt} \%$ to 101.9 $w t \%$. The excess of $100 \mathrm{wt} \%$ was provided by the amount of hydrogen consumption [12].

\section{Results and Discussions}

Table 3 shows the product distribution after the hydrocracking of AR samples at different temperatures for 2 hours under hydrogen pressure of $10 \mathrm{MPa}$, using a fixed bed reactor.

The yield of LF reached to $53.9 \mathrm{wt} \%$, the yield of liq- uid fractions $\left(<350^{\circ} \mathrm{C}\right)$ including gas product reached to $88.9 \mathrm{wt} \%$ in the hydrocracking for TBAR at the highest temperature of $470^{\circ} \mathrm{C}$. Also the AR conversion was increased from $56.7 \mathrm{wt} \%$ to $90.6 \mathrm{wt} \%$, when the hydrocracking temperature increased from $450^{\circ} \mathrm{C}$ to $470^{\circ} \mathrm{C}$. The amount of hydrogen consumption was the highest for MEAR. It should be explained by the lowest $\mathrm{H} / \mathrm{C}$ atomic ratio of corresponding feedstock. The $\mathrm{H} / \mathrm{C}$ ratio of MEAR was the lowest (1.66) as shown in Table 1.

Figure 2 summarized a dependence of each product yield on reaction temperature for AR samples. It was evident that the hydrocracking product was lightened as the increasing of reaction temperature. Hydrocracking reaction of all $\mathrm{AR}$ samples used in this research at the temperature of $470^{\circ} \mathrm{C}$ provided the largest amount of gas and LF, consequently the lowest yield of HF and bottom. The yield of MF was the highest at temperature of $460^{\circ} \mathrm{C}$ in all of AR samples, however the variation for yield of MF was not so high compared to the yields of the other products, by the increasing of reaction temperature.

The yields of gas products after the catalytic hydrocracking of the AR samples are illustrated in Figure 3. With the TBAR the highest yield of gases product was produced after the run of hydrocracking at the tempera-

\begin{tabular}{|c|c|c|c|c|c|c|c|c|c|c|c|}
\hline \multirow{2}{*}{ Samples } & \multicolumn{2}{|c|}{$\begin{array}{l}\text { Initial fractional } \\
\text { composition }\left(\mathrm{wt}^{\circ} \%\right)\end{array}$} & \multirow{2}{*}{$\begin{array}{l}\text { Temperature } \\
\left({ }^{\circ} \mathrm{C}\right)\end{array}$} & \multirow{2}{*}{$\begin{array}{l}\text { Hydrogen consumption } \\
\text { ( }\left(\mathrm{wt}^{\mathrm{O}} \%\right)\end{array}$} & \multirow{2}{*}{$\begin{array}{l}\text { AR conversion } \\
(w \mathrm{w} \%)\end{array}$} & \multicolumn{6}{|c|}{ Content of products (wt $\%)$} \\
\hline & $\mathrm{HF}$ & Vacuum residue & & & & Gas & LF & $\mathrm{MF}$ & $\mathrm{HF}$ & Bottom & Coke \\
\hline \multirow{3}{*}{ TBAR } & \multirow{3}{*}{55.8} & \multirow{3}{*}{44.2} & 450 & 0.5 & 56.7 & 3.7 & 29.3 & 22.0 & 38.0 & 5.3 & 2.2 \\
\hline & & & 460 & 0.4 & 74.9 & 5.7 & 43.0 & 26.1 & 23.6 & 1.5 & 0.5 \\
\hline & & & 470 & 0.9 & 90.6 & 11.4 & 53.9 & 23.6 & 8.6 & 0.8 & 2.6 \\
\hline \multirow{3}{*}{ DQAR } & \multirow{3}{*}{31.7} & \multirow{3}{*}{68.3} & 450 & 0.4 & 47.9 & 2.8 & 27.9 & 14.8 & 30.8 & 21.3 & 2.8 \\
\hline & & & 460 & 0.4 & 69.9 & 5.0 & 37.9 & 24.8 & 23.4 & 6.7 & 2.6 \\
\hline & & & 470 & 0.9 & 85.8 & 10.3 & 53.2 & 21.4 & 12.5 & 1.7 & 1.8 \\
\hline \multirow[b]{2}{*}{ MEAR } & \multirow[b]{2}{*}{33.6} & \multirow[b]{2}{*}{66.4} & 450 & 1.2 & 46.2 & 2.8 & 24.3 & 18.3 & 38.5 & 15.3 & 2.0 \\
\hline & & & 460 & 1.1 & 79.0 & 6.1 & 47.9 & 24.2 & 19.3 & 1.7 & 1.9 \\
\hline
\end{tabular}
tures of $450^{\circ} \mathrm{C}$ and $470^{\circ} \mathrm{C}$. Also the methane content in

Table 3. The product distribution after hydrocracking of atmospheric residue samples at different temperatures.

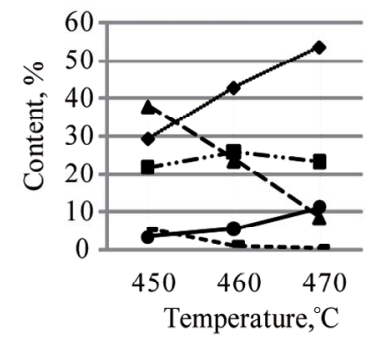

(a)

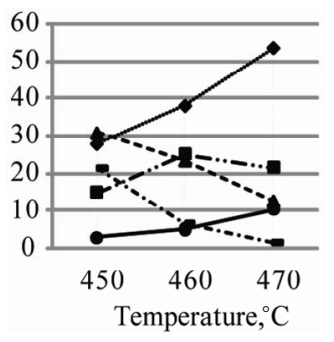

(b)

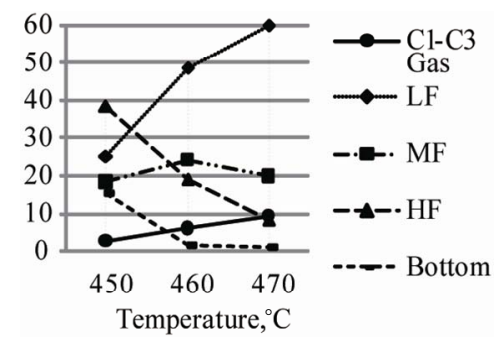

(c)

Figure 2. Relationship between the content of products and the temperature of hydrocracking. (a) TBAR; (b) DQAR; (c) MEAR. 
gases products was the lowest, but the propane content was the highest after every run of the hydrocracking for AR samples. The ratio of the contents of $\mathrm{C}_{1}-\mathrm{C}_{3}$ gases was nearly constant for the all of AR [13].

The contents of subfractions, hydrocarbons and the amount of sulfur in MF and HF after the hydrocracking of AR samples were shown in Table 4. The content of $\left(<254^{\circ} \mathrm{C}\right)$ subfraction was decreased, in place of it, the contents of $\left(<344^{\circ} \mathrm{C}\right),\left(>344^{\circ} \mathrm{C}\right)$ subfractions in MF were expanded as the increasing of reaction temperature of the hydrocracking. Also the content of $\left(<344^{\circ} \mathrm{C}\right)$ subfraction was decreased, in place of it, the contents of $\left(<496^{\circ} \mathrm{C}\right)$ subfraction in HF was expanded as the increasing of reaction temperature. It means that the hydrocarbons component became heavier in the MF and HF after the hydrocracking of all of AR samples as the increasing of reaction temperature.

The content of saturate hydrocarbons was decreased,

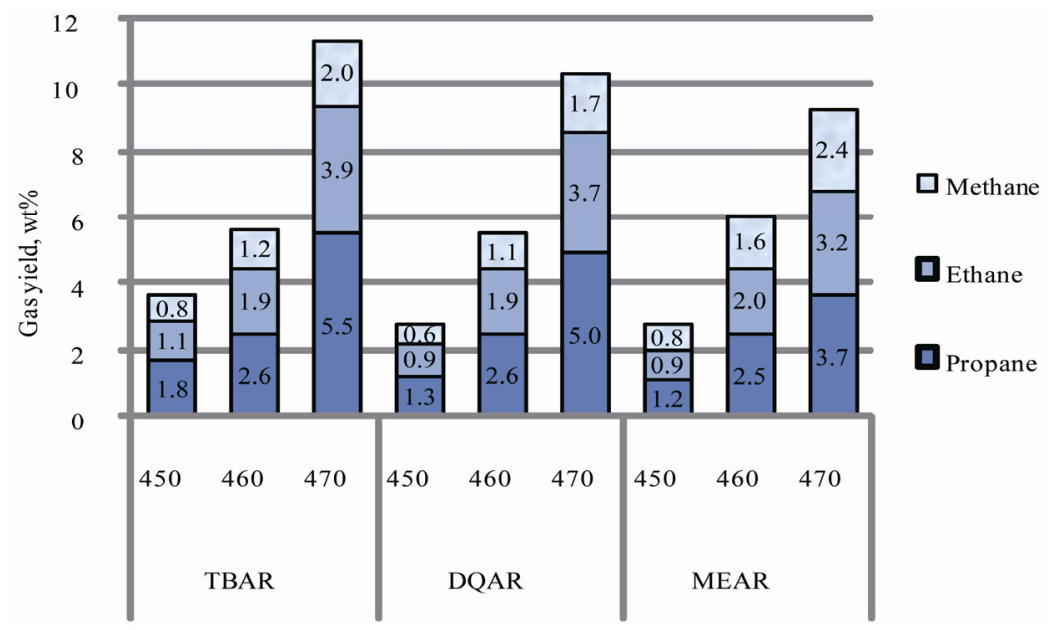

Figure 3. The yield of $C_{1}-C_{3}$ gases after the hydrocracking.

Table 4. Contents of subfractions, hydrocarbons and the amount of sulfur in hydrocracking products of AR samples (wt\%).

\begin{tabular}{|c|c|c|c|c|c|c|c|c|c|}
\hline \multirow{2}{*}{ Sample Temperature Properties } & \multicolumn{3}{|c|}{ TBAR } & \multicolumn{3}{|c|}{ DQAR } & \multicolumn{3}{|c|}{ MEAR } \\
\hline & $450^{\circ} \mathrm{C}$ & $460^{\circ} \mathrm{C}$ & $470^{\circ} \mathrm{C}$ & $450^{\circ} \mathrm{C}$ & $460^{\circ} \mathrm{C}$ & $470^{\circ} \mathrm{C}$ & $450^{\circ} \mathrm{C}$ & $460^{\circ} \mathrm{C}$ & $470^{\circ} \mathrm{C}$ \\
\hline Subfractions & \multicolumn{9}{|c|}{ In middle fraction (MF) } \\
\hline$<151^{\circ} \mathrm{C}$ & - & - & - & - & 0.1 & 0.1 & 0.1 & 0.2 & 0.2 \\
\hline$<254^{\circ} \mathrm{C}$ & 42.8 & 32.6 & 29.7 & 46.8 & 40.9 & 35.4 & 36.0 & 33.4 & 27.9 \\
\hline$<344^{\circ} \mathrm{C}$ & 53.9 & 60.1 & 61.9 & 48.1 & 54.9 & 59.6 & 59.5 & 60.1 & 63.6 \\
\hline$>344^{\circ} \mathrm{C}$ & 3.3 & 7.3 & 8.4 & 5.1 & 4.1 & 4.9 & 4.4 & 6.3 & 8.3 \\
\hline \multicolumn{10}{|l|}{ Content of hydrocarbons } \\
\hline Saturates & 78.7 & 76.3 & 69.1 & 79.1 & 79.3 & 74.6 & 66.2 & 62.7 & 51.5 \\
\hline Monoaromatics & 18.3 & 17.5 & 19.7 & 16.9 & 17.0 & 18.0 & 28.9 & 29.3 & 32.4 \\
\hline Polyaromatics & 2.8 & 5.5 & 9.9 & 2.0 & 3.0 & 6.3 & 4.8 & 7.8 & 15.7 \\
\hline Polar & 0.2 & 0.7 & 1.3 & 0.7 & 1.1 & 2.0 & 0.1 & 0.2 & 0.3 \\
\hline n-paraffins & 46.3 & 46.1 & 45.9 & 46.7 & 46.5 & 45.0 & 21.2 & 26.1 & 25.9 \\
\hline Sulfur & 19 & 29 & 35 & 9 & 14 & 21 & 180 & 330 & 750 \\
\hline Subfractions & \multicolumn{9}{|c|}{ In heavy fraction (HF) } \\
\hline$<254^{\circ} \mathrm{C}$ & 0.2 & 1.2 & 0.5 & 0.2 & 1.7 & 1.5 & 1.4 & 0.9 & 4.7 \\
\hline$<344^{\circ} \mathrm{C}$ & 34.3 & 21.3 & 13.4 & 27.3 & 30.3 & 14.4 & 22.3 & 23.4 & 15.1 \\
\hline$<496^{\circ} \mathrm{C}$ & 63.4 & 71.3 & 81.0 & 70.8 & 65.4 & 78.3 & 72.4 & 72.6 & 76.6 \\
\hline$>496^{\circ} \mathrm{C}$ & 2.1 & 6.2 & 5.1 & 1.7 & 2.6 & 5.8 & 3.9 & 3.1 & 3.6 \\
\hline n-paraffins & 41.1 & 37.3 & 29.4 & 40.4 & 37.7 & 32.4 & 18.6 & 20.5 & 14.8 \\
\hline Sulfur & 22 & 125 & 200 & 36 & 120 & 140 & 980 & 1160 & 2320 \\
\hline
\end{tabular}


but the contents of polyaromatic, polar hydrocarbons and the amount of sulfur compound were expanded in MF of TBAR as the increasing of temperature for hydrocracking. Also the amount of sulfur in HF was increased, by dependent of the reaction temperature. Summation of this result and the product distribution after hydrocracking of AR (Table 3), polyaromatic, polar hydrocarbons and sulfur compounds were concentrated in MF and HF because the large amount of light hydrocarbons produced from AR and moved to LF as an increasing of the reaction temperature [14].

The content of n-paraffinic hydrocarbons in HF was decreased by dependent of the reaction temperature. However the content of the n-paraffinic hydrocarbons was not changed in MF of TBAR. This result suggests the longer molecules of n-paraffin $\left(\mathrm{C}_{20}-\mathrm{C}_{32}\right)$ in $\mathrm{HF}$ were reacted better, than middle molecules of n-paraffin $\left(\mathrm{C}_{12}-\mathrm{C}_{20}\right)$ in MF during the hydrocracking reaction [15]. The contents of $n$-paraffins in MF and HF of TBAR and DQAR were similar, but MEAR's was around 2 times lower after hydrocracking because the hydrocarbon component of those AR samples and feed crude oils were the various $[12,13]$.

\section{Conclusions}

Atmospheric residue of Mongolian Tamsagbulag crude oil (TBAR) was tested for hydrocracking in the first time. In order to compare a hydrocraking reactivity of TBAR sample with Chinese Daqing (DQAR) and Arabian mixed Middle East (MEAR) samples were tested with commercial $\mathrm{NiMo} / \mathrm{Al}_{2} \mathrm{O}_{3}$ catalyst at different temperatures of $450^{\circ} \mathrm{C}-470^{\circ} \mathrm{C}$. Some conclusions can be drawn as follows:

1) In the hydrocracking of TBAR, the yield of liquid fractions including of gas product $\left(<350^{\circ} \mathrm{C}\right)$ expanded sharply as the increasing of reaction temperature. The yield of middle fraction (MF) from TBAR was the highest at temperature of $460^{\circ} \mathrm{C}$;

2) The polyaromatic, polar hydrocarbons and sulfur compounds were concentrated in MF and HF of TBAR because the large amount of light hydrocarbons produced from AR and moved to LF as the increasing of the reaction temperature;

3) With the hydrocracking of TBAR and DQAR, the content of the n-paraffinic hydrocarbons more decreased in HF than MF by dependent of the reaction temperature. This result suggests the longer molecules of $n$-paraffins $\left(\mathrm{C}_{20}-\mathrm{C}_{32}\right)$ in HF were reacted better, than the middle molecules of n-paraffin $\left(\mathrm{C}_{12}-\mathrm{C}_{20}\right)$ in MF during the hydrocracking reaction of TBAR, DQAR samples;

4) The contents of n-paraffinic hydrocarbons in MF and HF of TBAR and DQAR were similar, but MEAR's was around 2 times lower than those and the hydrogen consumption was the highest after hydrocracking for the MEAR, because the hydrocarbon component of those AR samples and feed crude oils were various.

\section{Acknowledgements}

The authors gratefully acknowledge the opportunity to carry out this work by the Advanced Fuel Group, Energy Technology Research Institute (ETRI), National Institute of Advanced Industrial Science and Technology (AIST), Japan.

\section{REFERENCES}

[1] B. Enkhsaruul and Y. Ohtsuka, "Cracking Behavior of Asphaltene in the Presence of Iron Catalysts Supported on Mesoporous Molecular Sieve with Different Pore Diameters," Fuel, Vol. 82, No. 13, 2003, pp. 1571-1577. doi:10.1016/S0016-2361(03)00094-2

[2] E. Fumoto, A. Matsumura, S. Sato and T. Takanohashi, "Kinetic Model for Catalytic Cracking of Heavy Oil with a Zirconia-Alumina-Iron Oxide Catalyst in Stream Atmosphere," Energy \& Fuels, Vol. 23, No. 11, 2009, pp. 5308-5311. doi:10.1021/ef9006164

[3] M. Kouzu, Y. Kuriki, K. Uchida, K. Sakanishi, Y. Sugimoto and I. Saito, "Catalytic Hydrocracking of Petroleum Residue over Carbon-Supported Nickel-Molybdenum Sulfide," Energy \& Fuels, Vol. 19, No. 3, 2005, pp. 725-730. doi:10.1021/ef049895h

[4] V. Simanzhenkov and R. Idem, "Crude Oil Chemistry," Marcel Dekker, New York, 2003.

[5] B. Shirchin, E. Nordov, D. Monkhoobor and A. Sainbayar, "Study on Main Physical and Chemical Characteristics of East Mongolian Petroleum," Journal of Industrial and Engineering Chemistry (Korea), Vol. 14, No. 4. 2003, pp. 423-425.

[6] E. Enkhtsetseg, B. Byambagar, D. Monkhoobor, B. Avid and A. Tuvshinjargal, "Determination of Sterane and Triterpane in the Tamsagbulag Oilfield," Advances in Chemical Engineering and Science, Vol. 1, No. 3, 2011, pp. 163-168. doi:10.4236/aces.2011.13024

[7] B. Khongorzul, "Feature of the Hydrocarbon Composition and High Molecular Compounds of the High Paraffinic Oil from Mongolia," Ph.D. Thesis, Russian Academy of Science, Tomsk, 2008, pp. 67-77.

[8] B. Shirchin, E. Nordov, D. Ganzorig and Ts. Tugsuu, "Study Review in the Fields of Mongolian Oil Chemical Technology for Last 10 Years," The Sustainable Development of Mongolia and Chemistry International Symposium, Ulaanbaatar, 11-14 September 2002, pp. 25-27.

[9] J. Sainbayar, D. Monkhoobor and B. Avid, "Determination of Trace Elements in the Tamsagbulag and TsagaanEls Crude Oils and Their distillation Fractions Using by ICP-OES," Advances in Chemical Engineering and Science, Vol. 2, 2012, pp. 113-117. doi:10.4236/aces.2012.21013

[10] A. Sainbayar, E. Nordov and D. Monkhoobor, "Comparison of Hydrocarbon's Composition of Main Oil Frac- 
tions between Tamsagbulag and Zuunbayan Oils, Mongolia," In: K. L. Montclaire, Ed., Petroleum Science Research Progress, Nova Science Publisher Inc., New York, 2008, pp. 329-349.

[11] Ts. Tugsuu, Y. Sugimoto and B. Enkhsaruul, "Catalytic Hydrocracking for Atmospheric Residue of Mongolian and Other Crude Oils," Proceedings of 4th International Conference on Chemistry, Green Chemistry and Advanced Technology, 7-9 October 2010, pp. 215-219.

[12] Y. Sugimoto, Y. Aihara, A. Matsumura, A. Ohi, S. Sato and I. Saito, "Processing of Middle East Crude with Canadian Oil Sands Bitumen-Derived Synthetic Crude Oil," Journal of the Japan Petroleum Institute, Vol. 49, No. 1,
2006, pp. 1-12.

[13] Y. Sugimoto, "Slurry Phase Hydrocracking of Heavy Oil over Ni-Mo/Carbon Catalyst," 16th Saudi Arabia-Japan Joint Symposium, Al Khobar, 5-6 November 2006.

[14] T. Kabe, A. Ishihara and W. Qian, "Hydrodesulfurization and Hydrodenitrogenation: Chemistry and Engineering," Wiley-Vch, Weinheim, 1999.

[15] B. Enkhsaruul and Y. Ohtsuka, "Hydrocracking of Asphaltene with Metal Catalysts Supported on SBA-15," Applied Catalysis A: General, Vol. 252, No. 1, 2003, pp. 193-204. doi:10.1016/S0926-860X(03)00469-1 